УДК 656.022.9

DOI: https://doi.org/10.32851/2708-0366/2021.9.5

Бойко В.В.

доктор економічних наук, професор, профресор кафедри менеджменту організацій, Національний університет «Львівська політехніка» ORCID: https://orcid.org/0000-0003-3968-1651

Вінник В.О. студентка,

Національний університет «Львівська політехніка»

Boiko Vitalii, Vinnyk Viktoriya Lviv Polytechnic National University

\title{
ІНСТРУМЕНТИ КОНТРОЛІНГУ В СИСТЕМІ ЕКОНОМІЧНОЇ БЕЗПЕКИ ПІДПРИЄМСТВА
}

\author{
CONTROLLING TOOLS \\ IN THE SYSTEM OF ENTERPRISE ECONOMIC SECURITY
}

У статті визначено стратегічну важливість контролінгу в процесах мінімізації ризиків невизначеності прийняття управлінських рішень на підприємстві. Ідентифіковано передумови обгрунтування інструментів контролінгу в системі економічної безпеки підприємства. Проведено SWOT-аналіз стану використання контролінгу вітчизняними підприємствами в системі їх економічної безпеки. Розроблено матрицю узгодження завдань і пріоритетних заходів контролінгу з базовими функціональними складовими частинами економічної безпеки підприємства (фінансовою, силовою, виробничою, ринковою, техніко-технологічною, кадровою, інформачійною та екологічною). Запропоновано реалізачію комплексу інструментів контролінгу в системі економічної безпеки, серед яких слід назвати інституційно-правові, фінансово-економічні, організаційно-управлінські, науково-методологічні та інформачійно-комунікаційні.

Ключові слова: контролінг, економічна безпека, інструменти, система, інформаційно-аналітичне забезпечення.

В статье определена стратегическая важность контроллинга в проиессах минимизации рисков неопределенности принятия управленческих решений на предприятии. Идентифицированы предпосылки обоснования инструментов контроллина в системе экономической безопасности предприятия. Проведен SWOT-анализ состояния использования контроллинга отечественными предприятиями в системе их экономической безопасности. Разработана матрица согласования заданий и приоритетных мер контроллинга с базовыми функциональныли составляющими экономической безопасности предприятия (финансовой, силовой, производственной, рьночной, технико-технологической, кадровой, информационной и экологической). Предложена реализация комплекса инструментов контроллинга в системе экономической безопасности, среди которых следует назвать институциионально-правовые, финансово-экономические, организационно-управленческие, научно-методологические и информационно-коммуникационнье.

Ключевые слова: контроллинг, экономическая безопасность, инструменты, система, информационно-аналитическое обеспечение.

The article identifies the strategic importance of controlling in the processes of minimizing the risks of uncertainty of management decisions in the enterprise. Scientific developments in the field of controlling and ensuring economic security of the enterprise are studied. Prerequisites for substantiation of controlling tools in the system of economic security of the enterprise (growing transformations and threats, expediency of coordination of managerial influences, need for optimization of information flows of the enterprise, necessity of monitoring of safe business processes, minimization of risks of making wrong administrative decisions) are identified. 
A SWOT-analysis of the use of controlling by domestic enterprises in the system of their economic security was conducted, which allowed identifying strengths and weaknesses, as well as potential opportunities and threats of enterprises. A matrix of coordination of tasks and priority controlling measures with the basic functional components of economic security of the enterprise, namely financial, power, production, market, technical and technological, personnel, information and ecological, has been developed. The implementation of a set of controlling tools in the economic security of the enterprise, including the following: institutional and law (formation of the regulatory framework for establishing subsystem interaction of the controlling apparatus and the economic security system), financial and economic (providing reliable monetary and resource support for controlling measures in the context of strengthening economic security), organizational and managerial (construction of a rational structure of coordination and balancing of powers in the process of forming information and analytical support for the implementation of security management decisions), scientific and methodological (development of innovative methods for assessing the effectiveness of controlling and economic security), information and communication (automation) management decisions and information data protection).

Key words: controlling, economic security, tools, system, information and analytical support.

Постановка проблеми. Безперевні процеси трансформації суспільно-економічних відносин і наростаючі виклики функціонування виробничо-господарських комплексів національної економіки формують передумови для перегляду усталених підходів до забезпечення організаційно-управлінської підтримки стабільного розвитку суб'єктів господарювання. За таких умов постає доцільність реалізації ефективних засобів і методів формування економічної безпеки підприємств, що потребує впровадження дієвих управлінських рішень на засадах мінімізації ризиків невизначеності інформаційного середовища розроблення та імплементації цих рішень. Ефективним інноваційно-організаційним апаратом формування адекватного інформаційно-аналітичного забезпечення прийняття управлінських рішень у системі економічної безпеки підприємства є контролінг. 3 огляду на це актуалізується доцільність розроблення теоретико-прикладних підходів до позиціювання контролінгу в системі забезпечення економічної безпеки підприємства.

Аналіз останніх досліджень і публікацій. Дослідженню проблем забезпечення економічної безпеки та імплементації методико-прикладних засад контролінгу присвячено наукові праці низки вчених. Зокрема, О. Власюком сформовано концептуальні та прикладні засади забезпечення економічної безпеки [4, с. 25-32]. Т. Васильців у своїх дослідженнях обгрунтував стратегію та механізми забезпечення економічної безпеки підприємницьких структур залежно від їх галузевої спеціалізаціï, розміру та структурно-функціональних параметрів господарювання [3]. Організаційно-економічні засади детінізації діяльності підприємств у системі національної економіки розроблені 3. Варналієм [2, с. 48-50]. О. Ляшенко сформувала методологію та організаційно-економічний інструментарій управління економічною безпекою підприємства [8].

Водночас теоретико-методичні й прикладні положення впровадження апаратних засобів контролінгу на підприємстві стали об'єктами досліджень таких науковців, як Г. Смовкіна (обгрунтовано місце та роль контролінгу в системі стратегічного та оперативного управління підприємством) [11, с. 330-332]; В. Папп і Н. Бошота (визначено базові принципи та функції фінансового контролінгу в підвищенні ефективності розвитку підприємства) [10, с. 91]; В. Корнієв (розроблено методичний підхід до впровадження маркетингового контролінгу на підприємстві) [5, с. 115]; Л. Ліпич, О. Хілуха та М. Кушнір (обгрунтовано детермінанти ідентифікації показників контролінгу персоналу та умови формування системи контролінгу кадрового забезпечення підприємства) [7, с. 116].

Попри наявність численних наукових розробок, практично поза увагою авторів залишились питання впровадження контролінгу на підприємстві як ефективної структурно-функціональної компоненти зміцнення його економічної безпеки. 
Формулювання цілей статті. Метою статті є розроблення ефективних інструментів контролінгу в системі забезпечення економічної безпеки підприємства. Для досягнення мети було поставлено завдання провести SWOT-аналіз стану використання контролінгу вітчизняними підприємствами в системі їх економічної безпеки, обгрунтувати параметри узгодження завдань і заходів контролінгу в розрізі базових функціональних складових частин цієї безпеки та сформувати комплекс заходів щодо імплементації запропонованих інструментів контролінгу в системі економічної безпеки.

Виклад основного матеріалу. Забезпечення економічної безпеки підприємств $€$ об'єктивною вимогою часу, що обумовлена наявністю перманентного негативного впливу структурно-функціональних компонент дестабілізуючого середовища (виклик, ризик, загроза, небезпека) на розвиток їх господарських бізнес-процесів. Формування надійної системи безпеки є стратегічно важливим з огляду на необхідність забезпечення сталого розвитку об’єкта, ймовірність виникнення конфліктних ситуацій, постійну дію внутрішнього та зовнішнього середовища, ймовірність виникнення форс-мажорних ситуацій, психологічний чинник (за наявності ефективної системи безпеки людина почувається впевненіше i, як наслідок, має більше передумов для досягнення поставлених цілей) [1, с. 149]. Побудова ефективної системи економічної безпеки підприємства неможлива без розроблення та імплементації ефективних управлінських рішень, що вимагає формування об'єктивного інформаційно-аналітичного базису мінімізації ризиків невизначеності середовища господарювання на засадах контролінгу.

Доцільність реалізації раціональних інструментів контролінгу в системі економічної безпеки підприємства посилюється з огляду на таке:

- наростаючі ринкові трансформації, що супроводжуються надмірними викликами та загрозами ведення господарської діяльності для підприємств, структуризація дестабілізуючого впливу яких вимагає забезпечення тактико-оперативної підтримки прийняття ефективних управлінських рішень;

- збалансування функціональних складових частин економічної безпеки, що потребує координації управлінських впливів у розрізі стратегічно важливих сфер функціонування підприємства;

- доцільність оптимізації інформаційних потоків на підприємстві на засадах мінімізації ризиків виникнення конфлікту інтересів та прийняття помилкових управлінських рішень;

- проєктування об’єктивної методології формування аналітичного базису оцінювання ефективності бізнес-процесів підприємства;

- реалізація засобів динамічного моніторингу та оперативного корегування стратегічних індикаторів економічної безпеки підприємства;

- узгодження підсистеми управління витратами через структурно-функціональні зв'язки контролінгу із системою економічної безпеки підприємства;

- формування дієвих механізмів контролю безпекових бізнес-процесів підприємства в контексті зміцнення його конкурентних позицій на цільових сегментах ринку.

Проведений SWOT-аналіз дав змогу визначити сучасний стан використання засобів контролінгу в системі економічної безпеки вітчизняних підприємств (табл. 1). Формування безпекових параметрів розвитку підприємства передбачає застосування інтегрованого підходу до координації та узгодження управлінських впливів, що спрямовані на побудову превентивних механізмів захисту від загроз внутрішнього та зовнішнього характеру. Таким підходом є контролінг, який функціонально спроможний гарантувати безпекові умови розвитку підприємства на засадах використання комплексного інструментарію координації, моніторингу та узгодження прийняття управлінських рішень, а також забезпечити можливість здійснювати оперативну діагностику загроз економічної безпеки підприємства на ранніх стадіях їх виникнення 3 
подальшим розробленням конкретних рекомендацій та пропозицій, які спрямовані на підвищення рівня цієї безпеки [6, с. 345].

Таблиця 1

Результати SWOT-аналізу використання контролінгу вітчизняними підприємствами в системі їх економічної безпеки

\begin{tabular}{|c|c|c|}
\hline \multirow[b]{2}{*}{ 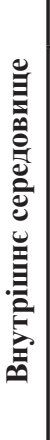 } & Сильні сторони & Слабкі сторони \\
\hline & $\begin{array}{l}\text { Наявність потужного трудового } \\
\text { потенціалу підприємств; багаторічний } \\
\text { досвід господарювання та доступність } \\
\text { імплементації передових світових практик } \\
\text { реалізації інструментів контролінгу в } \\
\text { системі економічної безпеки підприємства; } \\
\text { наявність розвиненого статистичного } \\
\text { базису для формування інформаційно- } \\
\text { аналітичного забезпечення системи } \\
\text { контролінгу; сформована методологія } \\
\text { оцінювання безпеки. }\end{array}$ & $\begin{array}{l}\text { Недостатній рівень професійної } \\
\text { кваліфікації персоналу у сфері контролінгу } \\
\text { та економічної безпеки; розбалансованість } \\
\text { організаційної структури та структури } \\
\text { управління підприємств; низький рівень } \\
\text { інноваційної активності господарюючих } \\
\text { суб’єктів; неузгодженість інструментів } \\
\text { контролінгу зі стратегічними цілями } \\
\text { системи економічної безпеки } \\
\text { підприємства; низький рівень техніко- } \\
\text { технологічної оснащеності підприємств. }\end{array}$ \\
\hline \multirow[b]{2}{*}{ 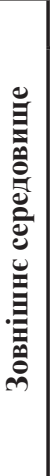 } & Можливості & Загрози \\
\hline & $\begin{array}{l}\text { Використання та впровадження } \\
\text { аутсорсингу економічної безпеки; } \\
\text { оптимізація відносин з основними } \\
\text { контрагентами; зміцнення конкурентних } \\
\text { позицій на ринку; входження підприємства } \\
\text { в інтегровані горизонтально-вертикальні } \\
\text { структури; покращення ринкового } \\
\text { портфеля підприємства та закриття } \\
\text { збиткових напрямів його діяльності; } \\
\text { мінімізація трансакційних витрат; } \\
\text { можливості оптимізації податкової бази } \\
\text { господарювання підприємства. }\end{array}$ & $\begin{array}{l}\text { Наявність ризику витоку за межі } \\
\text { підприємства інформації, що містить } \\
\text { комерційну таємницю; посилення } \\
\text { залежності від зовнішніх контрагентів; } \\
\text { ризики настання банкрутства підприємства } \\
\text { й зриву виконання його договірних } \\
\text { зобов’язань; посилення рівня конфліктного } \\
\text { середовища функціонування підприємства; } \\
\text { загрози посилення виникнення } \\
\text { рейдерських атак на підприємство; } \\
\text { недосконалість інституційного середовища } \\
\text { підприємств. }\end{array}$ \\
\hline
\end{tabular}

Джерело: власна розробка

Формування чітких параметрів розроблення та прийняття управлінських рішень вимагає з боку контролінгу побудови адекватного інформаційно-аналітичного базису, що має відповідати таким основним критеріям, як об'єктивність (достовірність інформаційних даних, що піддаються обробленню); своєчасність (гнучка передача інформації її кінцевим користувачам); оперативність (швидкість опрацювання інформаційних даних); повнота (цілісність управлінської інформації); верифікованість (забезпечення перевірки правдивості інформації); збалансованість (врахування інтересів і думок усіх учасників виробничо-господарського процесу). Інтеграція контролінгу в систему економічної безпеки підприємства передбачає узгодження його завдань та пріоритетних заходів з основними функціональними складовими частинами цієї системи (табл. 2).

Концептуальна модель реалізації контролінгу в системі економічної безпеки підприємства передбачає поєднання його структурних елементів організації та управління, основними серед яких $\epsilon$ ключові бізнес-процеси та витрати на їх розвиток; стратегічні центри відповідальності підприємства; підсистеми планування й бюджетування; підсистема управлінського обліку, яка побудована на основі центрів відповідальності та їх бюджетів; підсистема стратегічного управління, яка базується на аналізі ланцюга цінностей, стратегічного позиціонування факторів, що утворюють витрати; інформаційні потоки, що дають змогу оперативно фіксувати поточний стан 
виконання бюджетів ключових центрів відповідальності; підсистема моніторингу та аналізу результатів фінансово-економічної діяльності підприємства; ідентифікація причин відхилень фактичних індикаторів економічної безпеки від планових [9, с. 228]. Таким чином, ефективний контролінг передбачає, з одного боку, доцільність формування підсистеми структурно-функціональних заходів і процедур підприємства, а 3 іншого боку, інтеграцію цієї підсистеми в систему його економічної безпеки з урахуванням стратегічних компонентів здійснення виробничо-господарської діяльності. Забезпечення ефективності реалізації контролінгових процедур у системі економічної безпеки підприємства потребує формування та впровадження цілісного апарату контролінгу, основними інструментами якого визначено такі.

1) Інституційно-правові інструменти, що орієнтовані на побудову адекватного регламентного базису налагодження ефективної взаємодії засобів контролінгу із системою економічної безпеки підприємства на засадах раціонального збалансування впливу на процеси прийняття управлінських рішень формальних і неформальних інститутів (шляхом зменшення ролі останніх), компліментарності структурно-функціонального апарату контролінгу зі стратегічними, тактичними й оперативними цілями системи економічної безпеки підприємства, розроблення чітких регламентів та інструкцій покращення підсистемної взаємодії організаційних підрозділів підприємства, усунення інституційних бар'єрів розподілу інформаційних даних задля забезпечення підтримки оперативності прийняття та реалізації управлінських рішень, мінімізації інституційних ризиків невизначеності розвитку безпекових бізнес-процесів підприємства.

2) Фінансово-економічні інструменти, які передбачають формування надійного грошово-ресурсного забезпечення безперебійного функціонування підсистеми контролінгу на підприємстві шляхом проєктування чітких джерел та механізмів фінансування контролінгових процедур, активізації співпраці із суб'єктами банківсько-фінансового сектору, реструктуризації наявних підходів до бюджетування виробничо-господарської діяльності підприємства на засадах переходу до практики середньострокового планування та складання операційних бюджетів у розрізі стратегічних центрів відповідальності підприємства, стимулювання реалізації інвестиційно-інноваційних проєктів у сфері оптимізації інформаційних потоків системи економічної безпеки та мінімізації обсягу трансакційних витрат, імплементації заходів щодо підвищення рівня капіталізації комерційної інформації підприємства, утвердження практики проведення періодичного аудиту використання фінансово-економічних ресурсів підприємства задля попередження виникнення потенційних зловживань та нецільового використання коштів.

3) Організаційно-управлінські інструменти, що спрямовані на побудову раціональної апаратної структури забезпечення керованості засобів контролінгу та розвитку безпекових бізнес-процесів підприємства шляхом збалансування управлінських впливів між організаційними підрозділами підприємства, здійснення чіткого розмежування повноважень, обов'язків і відповідальності між суб'єктами різних ієрархічних рівнів управління, налагодження взаємодії між службами контролінгу та економічної безпеки підприємства або між відповідними центрами відповідальності, яким делеговано виконання функцій контролінгу та безпеки (фінансово-економічний відділ, бухгалтерсько-розрахункова служба, менеджерський апарат підприємства тощо), забезпечення координаційної підтримки прийняття управлінських рішень у сфері економічної безпеки, реструктуризації наявних підходів до організації обліку та контролю ключових бізнес-процесів підприємства.

4) Науково-методологічні інструменти, які покликані сформувати адекватний методичний базис функціонування апарату контролінгу та системи економічної безпеки підприємства на засадах розроблення інноваційних методик оцінювання рівня 
цієї безпеки в розрізі ії базових функціональних складових частин, формування системи безпекових індикаторів та їх гранично допустимих значень з урахуванням галузевої специфіки діяльності підприємства, організації механізмів моніторингу параметрів розвитку стратегічних детермінант забезпечення економічної безпеки, гарантування верифікації джерел отримання інформаційних даних прийняття управлінських рішень, використання економіко-математичного апарату моделювання та прогнозування стратегічних параметрів розвитку економічної безпеки підприємства, застосування засобів нівелювання соціально-психологічних впливів і суб'єктивних оцінок на параметри ефективності функціонування безпекових бізнес-процесів, обгрунтування методології встановлення допустимих меж відхилень фактичних показників від планових, формування передумов для посилення інтелектуальної складової частини розвитку персоналу підприємства.

5) Інформаційно-комунікаційні інструменти, що передбачають поширення практики впровадження сучасних інформаційних технологій та програмного забезпечення в процеси автоматизації прийняття поточних управлінських рішень, залучення ресурсних потужностей штучного інтелекту до процесів моделювання стратегічних параметрів розвитку потенційних ризиків і загроз підприємства, а також проєктування превентивних заходів протидії їх дестабілізуючому впливу, наближення архітектури управлінської системи підприємства в сегмент досягнення стратегічних цілей і тактичних завдань економічної безпеки, застосування інноваційних технологій захисту інформаційних даних від проявів несанкціонованого доступу та витоку інформації за межі підприємства.

Таблиця 2

Матриця узгодження завдань і заходів контролінгу 3 функціональними складовими частинами економічної безпеки підприємства

\begin{tabular}{|c|c|c|}
\hline $\begin{array}{c}\text { Функціональні } \\
\text { складові частини } \\
\text { економічної безпеки }\end{array}$ & Завдання контролінгу & Пріоритетні контролінгові заходи \\
\hline 1 & 2 & 3 \\
\hline Фінансова & $\begin{array}{l}\text { Інформування щодо } \\
\text { попередження ризиків } \\
\text { настання банкрутства. }\end{array}$ & $\begin{array}{l}\text { Системний моніторинг фінансово- } \\
\text { економічних показників, } \\
\text { удосконалення бюджетного процесу, } \\
\text { покращення фінансового обліку. }\end{array}$ \\
\hline Силова & $\begin{array}{l}\text { Протидія виникненню } \\
\text { рейдерських атак на } \\
\text { підприємство. }\end{array}$ & $\begin{array}{l}\text { Інформаційно-аналітична підтримка } \\
\text { юридичного супроводу, організація } \\
\text { цілодобового відеоспостереження } \\
\text { на підприємстві. }\end{array}$ \\
\hline Виробнича & $\begin{array}{l}\text { Формування раціональної } \\
\text { виробничо-галузевої } \\
\text { структури підприємства. }\end{array}$ & $\begin{array}{l}\text { Координація виробничих підрозділів, } \\
\text { удосконалення обліку виробничих } \\
\text { витрат, мінімізація собівартості } \\
\text { виробництва одиниці продукції. }\end{array}$ \\
\hline Ринкова & $\begin{array}{l}\text { Зміцнення конкурентних } \\
\text { позицій на ринку. }\end{array}$ & $\begin{array}{l}\text { Діагностика ринку, системне } \\
\text { опитування цільових споживачів } \\
\text { і покупців, стандартизація } \\
\text { маркетингових бізнес-процесів. }\end{array}$ \\
\hline Техніко-технологічна & $\begin{array}{l}\text { Інноваційна модернізація } \\
\text { виробничих потужностей. }\end{array}$ & $\begin{array}{l}\text { Впровадження передових технологій } \\
\text { розвитку виробничо-господарських } \\
\text { бізнес-процесів, автоматизація } \\
\text { оброблення інформаційних даних. }\end{array}$ \\
\hline
\end{tabular}


Продовження Таблиці 1

\begin{tabular}{|c|c|c|}
\hline 1 & 2 & 3 \\
\hline Кадрова & $\begin{array}{l}\text { Формування здорового } \\
\text { морально-психологічного } \\
\text { клімату в колективі. }\end{array}$ & $\begin{array}{l}\text { Структуризація інформаційних } \\
\text { потоків для уникнення конфлікту } \\
\text { інтересів, контролінг продуктивності } \\
\text { праці, розвиток персоналу. }\end{array}$ \\
\hline Інформаційна & $\begin{array}{l}\text { Мінімізація ризиків витоку } \\
\text { інформації, що містить } \\
\text { комерційну таємницю. }\end{array}$ & $\begin{array}{l}\text { Протидія несанкціонованому } \\
\text { втручанню, захист інформаційних } \\
\text { даних, формування системи } \\
\text { обмеженого доступу до комерційної } \\
\text { інформації. }\end{array}$ \\
\hline Екологічна & $\begin{array}{l}\text { Попередження екологічних і } \\
\text { техногенних катастроф. }\end{array}$ & $\begin{array}{l}\text { Моніторинг гранично допустимих } \\
\text { викидів у природні екосистеми, } \\
\text { екологічна стандартизація } \\
\text { та сертифікація виробничих } \\
\text { бізнес-процесів. } \\
\end{array}$ \\
\hline
\end{tabular}

Джерело: власна розробка

Висновки. Формування належного рівня економічної безпеки підприємства потребує обгрунтування дієвих інструментів контролінгу для мінімізації ризиків невизначеності прийняття управлінських рішень в умовах наростаючого впливу загроз на процеси господарювання. Інтеграція апарату контролінгу в систему економічної безпеки підприємства має відбуватися з урахуванням специфіки забезпечення цієї безпеки в розрізі ії базових функціональних складових частин. Для цього доцільною є реалізація таких інструментів контролінгу, як інституційно-правові (формування регуляторного базису налагодження підсистемної взаємодії апарату контролінгу та системи економічної безпеки), фінансово-економічні (забезпечення надійної грошової-ресурсної підтримки вжиття контролінгових заходів у контексті зміцнення економічної безпеки), організаційно-управлінські (побудова раціональної структури координації дій та збалансування владних повноважень у процесі формування інформаційно-аналітичного забезпечення імплементації безпекових управлінських рішень), науково-методологічні (розроблення інноваційних методик оцінювання ефективності контролінгу та рівня економічної безпеки) та інформаційно-комунікаційні (автоматизація прийняття управлінських рішень та захист інформаційних даних).

\section{Список використаних джерел:}

1. Бойко В. Формування системи безпеки як складової сталого економічного розвитку. Вісник Харківського національного технічного університету сільського господарства. Економічні науки. 2010. Вип. 105. С. 146-153.

2. Варналій 3. Теоретичні засади детінізації економіки України. Вісник Вінницького політехнічного інституту. 2014. № 1. С. 46-53.

3. Васильців Т. Економічна безпека підприємництва України: стратегія та механізми зміцнення : монографія. Львів, 2008. 384 с.

4. Власюк О. Теорія і практика економічної безпеки в системі науки про економіку. Київ : Національний інститут проблем міжнародної безпеки при Раді національної безпеки і оборони України, 2008. 48 с.

5. Корнієв В. Контролінг у системі управління маркетингом на підприємстві. Держава та регіони. Серія: Економіка та підприємництво. 2013. № 3 (72). С. 113-116.

6. Кузенко Т., Полтініна О. Формування системи забезпечення фінансової безпеки суб'єктів підприємництва на засадах контролінгу. Проблеми економіки. 2013. № 1. С. 345-352.

7. Ліпич Л., Хілуха О., Кушнір М. Контролінг персоналом як інструмент ефективного управління підприємством. Економічний часопис Волинського національного університету імені Лесі Украӥнки. 2021. № 2. С. 108-118. 
8. Ляшенко О. Концептуалізація управління економічною безпекою підприємства : монографія. Луганськ : вид-во СНУ ім. В. Даля, 2011. 400 с.

9. Нікітіна А. Концептуальна модель реалізації контролінгу в системі забезпечення економічної безпеки підприємств. Бізнес-Інформ. 2021. № 12. С. 226-229.

10. Папп В., Бошота Н. Фінансовий контролінг як основа ефективного управління фінансами підприємства. Молодий вчений. 2014. № 11 (14). С. 90-92.

11. Смовкіна Г. Контролінг як складова частина управління підприємством. Вісник соиіально-економічних досліджень. 2011. Вип. 2 (42). С. 329-335.

\section{References:}

1. Boiko V. (2010) Formuvannia systemy bezpeky yak skladovoi staloho ekonomichnoho rozvytku [Formation of the security system as a component of sustainable economic development]. Visnyk Kharkivskoho natsionalnoho tekhnichnoho universytetu silskoho hospodarstva. Ekonomichni nauky, no. 105, pp. 146-153.

2. Varnalii Z. (2014) Teoretychni zasady detinizatsii ekonomiky Ukrainy [Theoretical principles of de-shadowing of Ukraine's economy]. Visnyk Vinnytskoho politekhnichnoho instytutu, no. 1, pp. 46-53.

3. Vasyltsiv T. (2008) Ekonomichna bezpeka pidpryiemnytstva Ukrainy : stratehiia ta mekhanizmy zmitsnennia [Economic security of entrepreneurship of Ukraine: strategy and mechanisms of strengthening]. Monohrafiia. Lviv, p. 384.

4. Vlasiuk O. (2008) Teoriia i praktyka ekonomichnoi bezpeky v systemi nauky pro ekonomiku [Theory and practice of economic security in the system of economic science]. Natsionalnyi instytut problem mizhnarodnoi bezpeky pry Radi natsionalnoi bezpeky i oborony Ukrainy. Kyiv, p. 48.

5. Korniiev V. (2013) Kontrolinh u systemi upravlinnia marketynhom na pidpryiemstvi [Controlling in the marketing management system at the enterprise]. Derzhava ta rehiony. Seriia: Ekonomika ta pidpryiemnytstvo, no. 3 (72), pp. 113-116.

6. Kuzenko T., Poltinina O. (2013) Formuvannia systemy zabezpechennia finansovoi bezpeky subiektiv pidpryiemnytstva na zasadakh kontrolinhu [Formation of a system for ensuring the financial security of business entities on the basis of controlling]. Problemy ekonomiky, no. 1, pp. 345-352.

7. Lipych L., Khilukha O., Kushnir M. (2021) Kontrolinh personalom yak instrument efektyvnoho upravlinnia pidpryiemstvom [Personnel control as a tool for effective enterprise management]. Ekonomichnyi chasopys Volynskoho natsionalnoho universytetu imeni Lesi Ukrainky, no. 2, pp. 108-118.

8. Liashenko O. (2011) Kontseptualizatsiia upravlinnia ekonomichnoiu bezpekoiu pidpryiemstva [Conceptualization of economic security management of the enterprise]. Monohrafiia. Luhansk: vydvo SNU im. V. Dalia, p. 400.

9. Nikitina A. (2021) Kontseptualna model realizatsii kontrolinhu v systemi zabezpechennia ekonomichnoi bezpeky pidpryiemstv [Conceptual model of controlling implementation in the system of ensuring economic security of enterprises]. Biznes-Inform, no. 12, pp. 226-229.

10. Papp V., Boshota N. (2014) Finansovyi kontrolinh yak osnova efektyvnoho upravlinnia finansamy pidpryiemstva [Financial controlling as a basis for effective financial management of the enterprise]. Molodyi vchenyi, no. 11 (14), pp. 90-92.

11. Smovkina H. (2011) Kontrolinh yak skladova chastyna upravlinnia pidpryiemstvom [Controlling as an integral part of enterprise management]. Visnyk sotsialno-ekonomichnykh doslidzhen, no. 2 (42). 2011, pp. 329-335. 